\title{
STANDARDS OF LIVING IN UKRAINE, GEORGIA, AND POLAND: IDENTIFICATION AND STRATEGIC PLANNING
}

\author{
Yurii Kharazishvili, Olena Grishnova, and Bożena Kamińska
}

\begin{abstract}
The article determines the list of indicators of the standard of living of the population as a component of social security, including shadow indicators, without which the assessment of living standards is inadequate in reality. The authors substantiate the limits of safe existence through the definition of the vector of the indicators' threshold values. The paper identified the current state of the standards of living in Ukraine, Georgia and Poland through the integrated assessment from the standpoint of security, as well as outlined the most important threats. The researchers also scientifically substantiated the strategic benchmarks for the indicators of the standards of living considering three development scenarios that provide the fulfilment of the established sustainable development goals by means of adaptive regulation methods available in the control theory.
\end{abstract}

Keywords: standard of living, social safety, indicators, thresholds, integral index, economic security, sustainable development

JEL Classification: I310, C460, C610, H510, H520, H550, O210

\section{Author(s):}

\section{Yurii Kharazishvili}

Institute of Industrial Economics of the National Academy of Sciences of Ukraine, 2 Marii Kapnist Street, Kyiv, Ukraine, 03057

E-mail:yuri_mh@ukr.net

https://orcid.org/0000-0002-3787-1323

\section{Olena Grishnova}

Taras Shevchenko National University of Kyiv, 90A Vasylkivska Street, Kyiv, Ukraine, 03022

E-mail: grishnova@ukr.net

https://orcid.org/0000-0002-4178-1662

\section{Bożena Kamińska}

Deputy of the Sejm of the Republic of Poland, 4/6/8 Wiejska Street, Warsaw, Poland, 00-902

E-mail: biuro@bozenakaminska.pl

https://orcid.org/0000-0002-0654-870X

Citation: Kharazishvili, Y., Grishnova, O., \& Kamińska, B. (2019). Standards of living in Ukraine, Georgia, and Poland: identification and strategic planning. Virtual Economics, 2(2), 7-36.

https://doi.org/10.34021/ve.2019.02.02(1) 


\section{Introduction}

Standard of living is one of the most important socio-economic categories that are often referred to in discussions about the position of a person in society, the opportunities for meeting the needs of the residents, and the possibilities of human development.

The "standard of living" category is a complex and structurally systematic object of scientific economic and social research which in essence combines a wide range of socio-economic relations that characterise the peculiarities of the grade or level of subsistence and living conditions available to a person, family, social class, community and population in general. The peculiarity of this category lies in the fact that it cannot be described by a single indicator and may be objectively determined by a wide spectrum of characteristics relating to specific elements or certain manifestations of relations that arise in the process of society functioning. Therefore, it is important to clearly define the meaning of the "standard of living" concept.

It is quite common when the standard of living is identified with the notion of "well-being" which is defined in terms of access to consumption. From the standpoint of human development concept, the following is the most complete definition of the "standard of living" concept: the standard of living is a complex socio-economic category that reflects the level of development of the physical, spiritual and social needs of the population, the degree of their satisfaction, and conditions for the development and satisfaction of these needs. (Grishnova \& Kharazishvili, 2018)

The "standard of living" concept is often interpreted as the degree of satisfaction for material, spiritual and social needs available to the population. This definition reflects the statics of living standards. Meanwhile, the standard of living is a dynamic process, which is affected by numerous factors. On the one hand, the standard of living is determined by the composition and level of needs that are constantly changing. On the other hand, the standard of living is limited basing on the situation in the goods and services market, income of the population, and wages of employees. At the same time, both wages and living standards are determined by the scale and efficiency of production, scientific and technological progress, cultural and educational level of the population, the level of corruption, political situation, and the variety of other factors.

The International Labour Organization states that: "Everyone has the right to a standard of living adequate for the health and well-being of himself and his family, including food, clothing, housing and medical care and necessary social services, and the right to security in the event of unemployment, sickness, disability, widowhood, old age or other lack of livelihood in circumstances beyond his control." Every country implements these rights differently.

Raising the standard of living is simultaneously a goal and a priority of social development and is associated with social progress of society. The dynamics of the indicators of the standard of living indicate the results of economic development of the country, as well as the degree of socialisation of the economy. 
The indicators of income as the main source of satisfaction of personal material needs and increase of welfare take centre stage in the system of measuring the standard of living. We view the growth of income through the concept of human development as one of the major means that promote the increase of human capabilities and the level of well-being. However, income is not a measure of human happiness. It is definitely not enough to meet many urgent needs that go beyond material well-being. Thus, history demonstrates multiple examples, when the increase in national wealth was not accompanied by an adequate expansion of human freedom, strengthening of human health or improving the comfort of their lives. A similar situation was typical for the former countries of the socialist camp. Both the 1980s and these days witness the low (compared with neighbouring countries) standard of living becoming the cause of many negative processes - emigration, discomfort, social protests, etc., which, in general, pose a threat to national security.

Therefore, the objective of this paper is 1) to identify the existing standard of living in Ukraine, Georgia and Poland through integrated assessment from the standpoint of social security; 2 ) to detect the most important threats; and 3) to provide scientific substantiation of strategic indicators of living standards for three development scenarios that ensure the achievement of sustainable development goals through adaptive regulatory methods available in the management theory.

\section{Literature review}

A number of researchers investigated the standards of living as a component of social development, human capital and social security, particularly (Amosha \& Novikova, 2011; Amosha et al., 2016; Antoniuk et al., 2012; Arts, 2017; Bilan et al., 2019; Biermann, 2017; Cherenko, 2006; Dźwigoł \& Dźwigoł-Barosz, 2018; Głowski \& Kvilinskyi, 2017; Ivanov et al., 2017; Kaźmierczyk \& Akulich, 2018a,2018b; Koval, 2012, 2016; Kolot, 2010; Kvilinskyi et al., 2017; Kwilinski, 2018; Libanova et al., 2013; Laiko \& Kwiliński, 2017;Lakhno et al., 2018; Mazurkiewicz \& Lis, 2018; Mishchuk et al., 2018; Ngo, 2018; Novikova et al., 2018; Pająk et al., 2016a, 2016b; Peker et al., 2014; Raudeliūnienè et al., 2014; Trzeciakowski, 2018; Tkachenko et al., 2019; Tvaronavičienė et al., 2014;Vosylius et al., 2013; Winiarczyk-Razniak \& Razniak, 2011;Yang et al., 2018; Yakubovskiy et al., 2017; Yevdokimov et al., 2018) and others.

According to (Amosha and Novikova, 2011), the human potential development in Ukraine is increasingly becoming a strategic direction of state and regional governance. However, the competence of the Cabinet of Ministers of Ukraine regarding the quality of life and living standards of the population has not yet been specified; and therefore human and social development indicators are not included in the indicators of its effectiveness.

(Libanova et al., 2013) emphasizes that the strategic path of Ukrainian society modernisation is to improve the quality of life. Furthermore, the scholar analyses foreign experience and suggests a system of indicators and methodology for calculating the integral index. 
(Kolot, 2010) substantiates in his work the falsity of existing paradigms and myths that economic growth automatically creates preconditions and possibilities for solving problems in the field of social development. The researcher demonstrates that economic growth is not a guarantee of social security without an active social policy, which includes, in particular, redistributive measures of the state.

On the other hand, (Antoniuk et al., 2012) has further developed theoretical and methodological approaches to the definition of "decent living standards" and "quality of life" concepts, factors of their formation and role in the system of ensuring sustainable development of Ukraine. The scholar has provided the theoretical basis for the social potential of sustainable development, analysed the level and quality of life of the population at the regional level, evaluated regional differences in the welfare of the Ukrainian population.

Whereas (Novikova, 2018) explores the current state and burning issues of social security according to experts' estimations and substantiates the theoretical approaches and empirical dimensions of social security in Ukrainian society.

At the same time, (Yashchyshchyna, 2012) has grappled with the problems of social orientation of the innovative economy and has revealed the attributes of its socio-economic nature. As an example, she has described the social orientation of the EU and Ukraine's strategic documents and has analysed the trends of the interrelation between innovation and social development within their national economies.

(Koval, 2012) has examined the main approaches to the definition of the essence of social security: in the traditional (lack of threats to society) and alternative (no threat to society) understanding. Moreover, he has also justified the sets of indicators for quantitative measurement of the level of social security in the traditional and alternative sense.

While (Cherenko, 2006) delved into the problems of studying the standard of living of the population of Ukraine taking into account the specifics of the development of socio-economic processes. The scholar even developed the necessary methodical tools for assessing the living standards of the population.

(Mishchuk et al., 2018) have argued in their papers that significant differences in the standard of living of the population, which, in particular, are evident through the excessive income inequality, may have dangerous consequences for the sense of social injustice and the formation of negative migratory sentiment on this basis.

Despite the enormous importance of the conducted research, the issue of identifying the status of living standards from the standpoint of economic security was left out of attention the definition of the dynamics of integral indices, their comparison with integral threshold values, the consideration of shadow social security indicators, and the scientific substantiation of strategic guidelines for sustainable development strategies. 


\section{Methods}

The manifestations of human livelihoods and their needs are very diverse; therefore, it is impossible to allocate income as one universal indicator for the complete assessment of living standards of the population. This requires a cumulative system of features, indicators and parameters that, in their unity, are able to reflect the state of satisfaction of social needs according to their individual types, assess the level of life guarantees, conditions for the formation and distribution of material goods, spiritual benefits, and services in the country.

\subsection{Indicators of the standard of living}

A holistic system of indicators of the standard of living of the population should consist of both quantitative and qualitative indicators, grouped according to certain features. However, the practitioners use only the indices of material consumption, indices of physical volumes of consumed services, needs satisfaction coefficients, etc. We suggest a system of indicators and a methodology for evaluating them which allows assessing the conditions in a society for meeting human needs most accurately, basing on key macroeconomic indicators, taking into account shadow employment and shadow wages without which the assessment of living standards is inadequate.

The standard of living as a component of social security is characterised by the following indicators (Grishnova \& Kharazishvili, 2018):

1. labour use level (the ratio of the optimal demand for labour to its supply) (S);

2. compensation of employees in output (S);

3. GDP created by shadow employment and wages, \% of GDP (D);

4. shadow employment to total employment (D);

5. expenditure on education to output, \% (S);

6. healthcare expenditure to output,\% (S);

7. the ratio of average wages to a living wage (S);

8. wage share in the structure of income, $\%(S)$;

9. pension expenditure to output, \% (D);

10. pension fund deficit to output, \% (D).

In order to calculate a great number of the indicators of the standard of living, we use the original author's model of the aggregate supply function using the modified celebrated CobbDouglas production function (Kharazishvili, 2019):

$$
V_{t}^{S}=e^{\gamma t}\left[N_{e f, t}\left(P_{t}\right) \frac{W_{t}}{P_{t}} k_{s n}\right]^{a_{t}}\left[\vartheta_{t}\left(I_{t}\right) K_{t}\left(K_{t-1}, I_{t-1}, A_{t-1}, P_{t-1}\right)\right]^{1-a_{t}}
$$

where: $V$ - is output;

$e^{x}-$ is the scientific and technological progress, STP;

$\gamma$ - is STP rate; 
$L-$ is labour costs $\left(L=N_{e f}(W / P) k_{s n}\right)$;

$N_{e f, t}=\xi_{t} N_{t}$ is the effective number of taxpayers (hired workers plus another category of employed, normalised to the equivalent of employees);

$\xi_{t}$-is the share of the number of taxpayers in total employment;

$N_{t}-$ is total employment; $W$ is average nominal wages of employees;

$k_{s n}-$ is social load index;

$\vartheta-$ is capital to net sales ratio;

$I$ - is investment;

$A$ - is consumption of fixed capital;

$K$ - is cost of capital;

$a-$ is coefficient of elasticity, COE;

$P_{t}-$ is GDP (GVA) deflator;

$t-$ is the period of time.

Generally, part of the indicators of living standards (wage share, educational expenditures, healthcare expenditures, pension expenditures and pension fund deficit) is calculated relative to the GDP of each country. Sometimes it leads to a ridiculous or absurd result in countries with a high level of corruption and shadow economy, as in Ukraine, for instance: such definition of outlined indicators results in their best value among economically developed countries. Nevertheless, their real absolute values are extremely low; they are insufficient even when compared to less developed countries. This can be explained by the artificial increase of intermediate consumption and corresponding reduction in GDP relatively to which these indicators are calculated. Therefore, it is more appropriate to measure these indicators relative to the output rather than the GDP, which is artificially understated because of the massive shadow economy development.

The calculation of our chosen indicators of the standard of living is carried out according to the following method:

1. Labour use level (the ratio of the optimal demand for labour to its supply) $k_{l, t}$. Microeconomics substantiates that the maximum profit can be obtained when the marginal product of labour $P$ is equal to the nominal wage rate $W$ :

$$
P \frac{\partial V}{\partial L}=W
$$

After applying the transformation to the output function $V$, we can get the function of optimal demand for labour $N_{t}^{D}(P)$ (Kharazishvili \& Liubich, 2006; Kharazishvili et al., 2016):

$$
N_{t}^{D}=\frac{\vartheta_{t} K_{t} P_{t}}{\xi_{t} W_{t} k_{s n}}\left(e^{\gamma t} a_{t}\right)^{\frac{1}{1-a_{t}}}
$$


On the other hand, if we use household utility function $U=\sqrt{y F}$, which reflects the households' possibility to receive income $y$ considering that they have free time $F$ according to the method of Lagrange multipliers, we can obtain an equation for labour supply function $N^{S}(W)$ for the case of money illusion (Tarasevich et al., 1999):

$$
N^{S}=\frac{T_{N}}{2}-\frac{r K^{*}}{2 W}=\frac{T_{N}}{2}-\frac{I_{P} T_{N}}{2 W}=0.5 T_{N, t}\left(1-\frac{I_{P, t}}{W_{t}}\right)
$$

where: $T_{N}$ - is average annual population;

$r$ - is marginal productivity of capital;

$K^{*}$ - is property (capital) owned by households;

$I_{P}$ - is income per capita received from property owned by households.

Then, the labour use coefficient can be defined as the ratio of the function of optimal demand for labour $N_{t}^{D}\left(P_{t}\right)$ to the labour supply function $N_{t}^{S}\left(W_{t}\right)$ :

$$
k_{l, t}=\frac{N_{t}^{D}\left(P_{t}\right)}{N_{t}^{S}\left(W_{t}\right)}
$$

2. Compensation of employees in output $a_{t}$. It's a common fact that social and labour sphere is an integral part of the economy. Individual immediate needs, interests, standard of living is its major focus. At the same time, the very individual is the main element of the productive forces of society; moreover, the success of economic and social reforms largely depends on the work motivation of individuals. Therefore, the share of the compensation of employees in output is one of the main indicators that gives an idea of the real level of socioeconomic development in the country. According to the System of National Accounts (SNA), compensation of employees includes wages and salaries payable in cash or in kind, social insurance contributions payable by employers, which include contributions to social security schemes, actual social contributions to other employment-related social insurance schemes and imputed social contributions to other employment-related social insurance schemes.

The application of the aggregate supply function model allows calculating the elasticity coefficients of the production function at labour and capital costs basing on the official statistics for the country, regions and major economic activity types that determine the distribution of income between labour and capital:

$$
a_{t}=\frac{\xi_{t} N_{t}^{D}\left(P_{t}\right) \frac{W_{t}}{P_{t}} k_{s n}}{V_{t}}
$$


3. GDP created by shadow employment and wages $k_{\text {shadow_LP, }}$. Low wages is the result of the current imperfect Ukrainian tax system. Paradoxically, the main component of tax revenue is labour, more precisely, payroll. Due to all charges and deductions, about $75 \%$ of tax revenues are directly or indirectly linked to payroll. However, at the same time, wage in Ukraine is one of the lowest in the world. Here we can see an incredible paradox: the most oppressed production factor - labour - has become the largest source of revenue of the country's budget. This reality is the outcome of the disproportions between the primary production factors (labour and capital) which results in unjustifiably high tax burden on income of both the population and business.

The application of the method of calculating shadow GDP that we have developed and tested (Kharazishvili, 2019) makes it possible to calculate the internal part of GDP which is created by the shadow economy taking into account the consumption multiplier $\left(L P_{\text {shadon, } t}\right)$. Consequently, the share of GDP created by shadow employment and wages will determine the level of the shadow economy in GDP:

$$
k_{\text {shadow } L P, t}=\frac{L P_{\text {shadow } t}}{G D P_{\text {of }, t}} \cdot 100 \%
$$

4. Shadow employment to total employment $k_{\text {shadow_ } N, t}$. Shadow employment is an indisputable fact in a transformational economy, and its illegality is due to the weakness of socio-economic institutions. The increase in shadow employment leads to the production reduction in the main types of economic activity, low wages in production, high level of poverty of the working population, high level of taxation of legal business, contributions to state social funds, low compliance with established laws and, subsequently, loss of confidence to the law enforcement and judicial system of the state.

At the same time, employment in the shadow economy facilitates the development of new entrepreneurial abilities of an individual, the full implementation of his/her ability to work, adaptation of the workforce to modern market conditions. The ability of an employee to apply his/her ability to work and his/her personal motivation to obtain decent work remuneration (in most cases) determine the relatively high efficiency of the employment formation mechanism in case of shadow economy. Nevertheless, they require increased labour intensity from the employees with no state security guarantees in case of illness, accident, old age, etc. Therefore, individuals significantly reduce their future pension.

Hence, in a certain way employment in the shadow sector can protect labour potential, it contributes to increasing current incomes, and often even assures the primary survival of a particular share of the population. On the other hand, employment in the shadow economy distracts a lot of resources and efforts to conceal the activity itself, as well as its results, generates additional expenses of business entities, leads to the loss of mandatory tax revenues 
due to shadow wages that are vital for the state to perform its functions, and contributes to corruption development. Therefore, the quantitative determination and consideration of shadow employment, shadow wages and the search for mechanisms for its reduction is very relevant.

If we use the model of the aggregate supply function (Kharazishvili \& Liubich, 2006), it is possible to measure the capital to net sales ratio for both official and shadow economy for the country in general, regions and major economic activity types. Measuring the capital to net sales ratio gives grounds to the hypothesis of the relationship between the capital to net sales ratio in the shadow economy and the level of shadow employment (Kharazishvili, 2019). With the use of the official and forecast statistics on the average annual number of employed and hired employees, it is possible to determine the size of shadow employment proportionally to the capital to net sales ratio. At the same time, the ratio of shadow employment $N_{\text {shadow, }}$ to total employment $N_{t}$ will determine the level of shadow employment:

$$
k_{\text {shadow_N,t }}=\frac{N_{\text {shadow }, t}}{N_{t}}
$$

5. Public expenditure (consolidated budget expenditure) on education to output $k_{e d u, t}$. It is well-known that education is an institution that influences all spheres of society and it is a significant factor in achieving high rates of economic growth and social well-being. It is the constant growth of educational expenditures that help developed countries to maintain leading positions in the world economy, and, in most of them, the state share predominates in the structure of educational expenditure. At the same time, it is not just a single citizen who benefits from the high level of education; it is society as a whole, since raising the level of general and professional training and qualifications of each employee is an important factor in the labour productivity and economic development growth of the country. In the light of the aforementioned, the fifth indicator will be measured as follows: public expenditure on education $G_{e d u, \mathrm{t}}$ to output $V_{\mathrm{t}}$ ratio:

$$
k_{e d u, t}=\frac{G_{e d u, \mathrm{t}}}{V_{\mathrm{t}}} 100 \%
$$

6. Public healthcare expenditure to output $k_{\text {health, }}$. The right to healthcare, medical care and health insurance is one of the fundamental civil rights and is usually set out in the Basic Law (for example, in Ukraine it is Article 49, in Georgia - Article 37 of the Constitution). Healthcare is provided by public funding of the relevant socio-economic, health and sanitation, health improvement and prevention programmes. The state promotes the development of medical institutions of all forms of ownership. The indicator shows what proportion of public resources the state allocates to preserving the health of its citizens and it is calculated as the ratio of expenditures on healthcare $G_{\text {health, }}$ to output $V_{\mathrm{t}}$ in per cent: 


$$
k_{\text {health, },}=\frac{G_{\text {health, }}}{V_{\mathrm{t}}} 100 \%
$$

7. The ratio of average wages to a living wage $k_{w / L W, t}$. This indicator is one of the most important social security indicators. A living wage is a state standard used for general assessment of living standards in the country.

Living wage is the pivotal basis of the social policy of the state, since the other standards and results of the social sphere reform and the minimum rates are most consistent with this indicator. It is also one of the important socio-economic indicators the application of which on a massive scale makes it possible to identify objective patterns and measure the general trends in the standard of living both quantitatively and qualitatively. Such measuring is an adequate basis for making informed managerial decisions. Therefore, the closer the standard of living is to the critical level is, the more important social role the state plays, moreover, it bears the higher responsibility it bears for the social consequences of economic policy implemented in the country.

The definition of the living wage should be related to socio-economic conditions in the country and should take into account the need to shift to international standards in a context of growing globalisation. The poverty of the working population who receive wages that are not sufficiently higher than the living wage or even subsistence is a significant issue and it is reflected in the ratio of average wages $W_{t}$ to the living wage $L W_{t}$.

$$
k_{w / L W, t}=\frac{W_{\mathrm{t}}}{L W_{\mathrm{t}}} 100 \%
$$

Taking into account the EU and ILO standards (Zavora, 2013) for a decent standard of living wage should be at least 3 times higher than the living wage (lower threshold). According to the relevant European standards, the average wage should be 5-6 living wages.

8. Wage share in the structure of income $k_{W / D, t}$. Income of the population is the sum of monetary and in-kind compensations, particularly: wages and salaries (including income received from abroad), profits and mixed income, property income, social benefits and other current transfers. A high share of wages, along with a low percentage of social income support, indicates the employment efficiency, and the social self-sufficiency of employees.

The indicator is calculated as the ratio of the aggregate nominal wages and salaries of the population $W_{p o p, t}$ to the total income of the population $D_{p o p, t}$ : 


$$
k_{W / D, t}=\frac{W_{p o p, t}}{D_{p o p, t}} 100 \%
$$

9. Pension expenditure to output $k_{\text {pens, }}$. Pension expenditures perform one of the social security functions. This function is implemented through the accumulation of financial resources in special funds and their distribution for different purposes. These are the actions of state bodies, local self-government, organisations regarding the contributions to social security funds, the allocation of these funds for the payment of pensions, assistance, servicing of pensioners, etc.

As a general matter, the Pension Fund balance under consolidated scheme which provides the functioning of the $1^{\text {st }}$ tier is defined as follows (Koval, 2012):

$$
N_{\text {eff }} \cdot W_{\text {ave }} \cdot n=k_{\text {pens }} \cdot P_{\text {ave }}
$$

where: $N_{\text {eff }}$ - is effective number of payers of insurance contributions;

$W_{a v e}$ - is average wage (average value of the sum relevant for payable insurance contributions);

$n$ - is the size (\%) of insurance contribution;

$k_{\text {pens }}-$ is the number of pensioners;

$P_{a v e}-$ is the average pension.

If the left side of the equation (own revenues of the pension fund) is less than the right side (pension fund expenditures), there is a deficit of the pension fund budget covered only from the state budget. The number of retirees is the only objective variable in the equation (subject to the legislative unchanged retirement age). The other variables are subjective; therefore, they can be potentially regulated by administrative or economic levers.

The ninth indicator is calculated as the ratio of annual aggregate expenditures $\left(G_{p e n s, t}\right)$ of the Pension Fund (PF) to output $V_{t}$ :

$$
k_{p e n s, t}=\frac{G_{p e n s, t}}{V_{t}} 100 \%
$$

10. Pension fund (PF) deficit to output $k_{d e f_{-} P F U, t}$. The indicator reflects the output share that should cover the deficit of the PF budget and is calculated as the ratio of the PF budget deficit $D e f_{P F U, t}$ to output $V_{t}$ : 


$$
k_{\text {def_PFU,t }}=\frac{D e f_{P F U, t}}{V_{t}} 100 \%
$$

One of the reasons for the disparity in the Pension Fund budget is the imbalance of its revenues and expenditures due to the great extent of shadow economy and low wages.

\subsection{Integral assessment of the standard of living}

The methodology of integral assessment of the standard of living includes the following tasks:

- defining the structure of the assessment of the standard of living;

- forming a list of indicators and components of the evaluation object;

- selecting the form of the integral index;

- selecting the method of valuation;

- scientific substantiation of the dynamic weight coefficients;

- scientific substantiation of the threshold values' vector.

Similarly to the methodology for assessing the level of economic security (Kharazishvili, 2014; Amosha et al., 2016) (of the country, region, types of economic activities) that we recommended and successfully tested in practice we suggest using a methodology for integrating 10 indicators of the standard of living described above which includes the following elements:

- the form of the integral index is multiplicative:

$$
I_{t}=\prod_{i=1}^{n} z_{i, t}^{a_{i}} ; \quad \sum a_{i}=1 ; \quad a_{i} \geq 0
$$

where: $I-$ is an integral index;

$z$ - is a normalised indicator;

$a-$ is a weight coefficient.

- the method of valuation is combined:

$$
S: z_{i}=\frac{x_{i}}{k_{\text {norm }}}, \quad D: z_{i}=\frac{k_{\text {norm }}-x_{i}}{k_{\text {norm }}}, \quad k_{\text {norm }}>x_{\max }
$$

where: $x$ - is an indicator value;

$k_{\text {norm }}-$ is a valuation factor.

- weight coefficients are dynamic: based on the application of the Main Components and the Moving Matrix methods: 


$$
C_{i} \times D_{i}=\left(\begin{array}{l}
d_{1} c_{11}+d_{2} c_{12}+\ldots+d_{j} c_{1 j} \\
d_{1} c_{21}+d_{2} c_{22}+\ldots+d_{j} c_{2 j} \\
\ldots \ldots \ldots \ldots \ldots \ldots \ldots \ldots \ldots \ldots \ldots \\
d_{1} c_{j 1}+d_{2} c_{j 2}+\ldots+d_{j} c_{j j}
\end{array}\right)=\left(\begin{array}{l}
w_{1} \\
w_{2} \\
\ldots \\
w_{j}
\end{array}\right), \quad a_{i}=\frac{w_{i}}{\sum w_{i}}
$$

where: $C$ - is the matrix of absolute values of factor loadings;

$D$ - is the vector-matrix of dispersions.

Over time, substantial changes in the political and external economic situation lead to substantial changes in empirical estimates of econometric relationships, which, in their turn, lead to changes in weight coefficients.

The Moving Matrix method is based on the application of the Main Components method; it lies in the sequential shift of the matrix of the minimum required size along the time period and the determination of the weight coefficients for the last time period each and every time. Minimum required matrix size (number of rows $(n)$ - periods of time) is determined basing on the principle that the number of indicators (the number of columns $(m)$-main components) is equal to the number of positive eigenvalues of this matrix. Typically, the minimum required matrix size is equal to $(n+1) \times n$.

- threshold values are the results of calculations using a set of methods (mainly analytic ones): functional dependencies; macroeconomic models; stochastic; nonlinear dynamics; legislative approach; heuristic; analogue approaches; expert assessments; taking into account evaluations of international organisations.

The vector of threshold values is given for each indicator, namely: lower critical value, lower threshold, lower optimal value, upper optimal value, upper threshold, and upper critical value. A pair of optimal values forms a homeostatic plateau within which there is a negative feedback and the best conditions for the system existence are created; moreover, the violations of critical values can even lead to the destruction of the system. An integral convolution is made both for indicators of the standard of living and for their threshold values which allows the researchers to particularly identify the standard of living.

Consequently, measuring the threshold values is quite closely related to the concept of the dynamic stability of economic system and its individual components, or to homeostasis mechanism. Without this comparison, we will have the dynamics of integral indices which will determine their increase / decrease in certain periods that may lead to an erroneous conclusion regarding the integral index maximisation, nevertheless it is worth finding it within the thresholds, preferably optimal values (within the homeostatic plateau boundaries).

Given the definition of the threshold vector, we suggest to extend the "homeostatic plateau" proposed by Van Gigch (Van Gigch, 1981), which differs by adding a range of threshold and critical values to the area of neutral inverse communication Fig.1. Each dynamical system has 
marginal stability, so the crossing of critical points does not determine immediately the change of the type of inverse communication: first, the inverse relationship decreases by the exponential, and then another type of connection grows along the exponential.

If there is no chance to apply functional dependencies or macroeconomic models (in case of their absence), a situation often arises when, on the basis of different sources of information, it is possible to formulate a sample (in this case, a sample of the indicators' limit values), which number of elements is more than 20 (the method can be used for both large and small samples). In this case, the vector of threshold values can be derived from the t-criterion (Paniotto et al., 2004).

Using the sample mentioned above, we construct the probability density function with the calculation of statistical parameters: mathematical expectation, mean squared deviation, and skewness. Considering all the diversity of types of probability density functions for all types of indicators we can distinguish the types with a characteristic distribution law: normal, lognormal and exponential, for which there are suggested equations for determining the vector of threshold values (Kharazishvili, 2019).

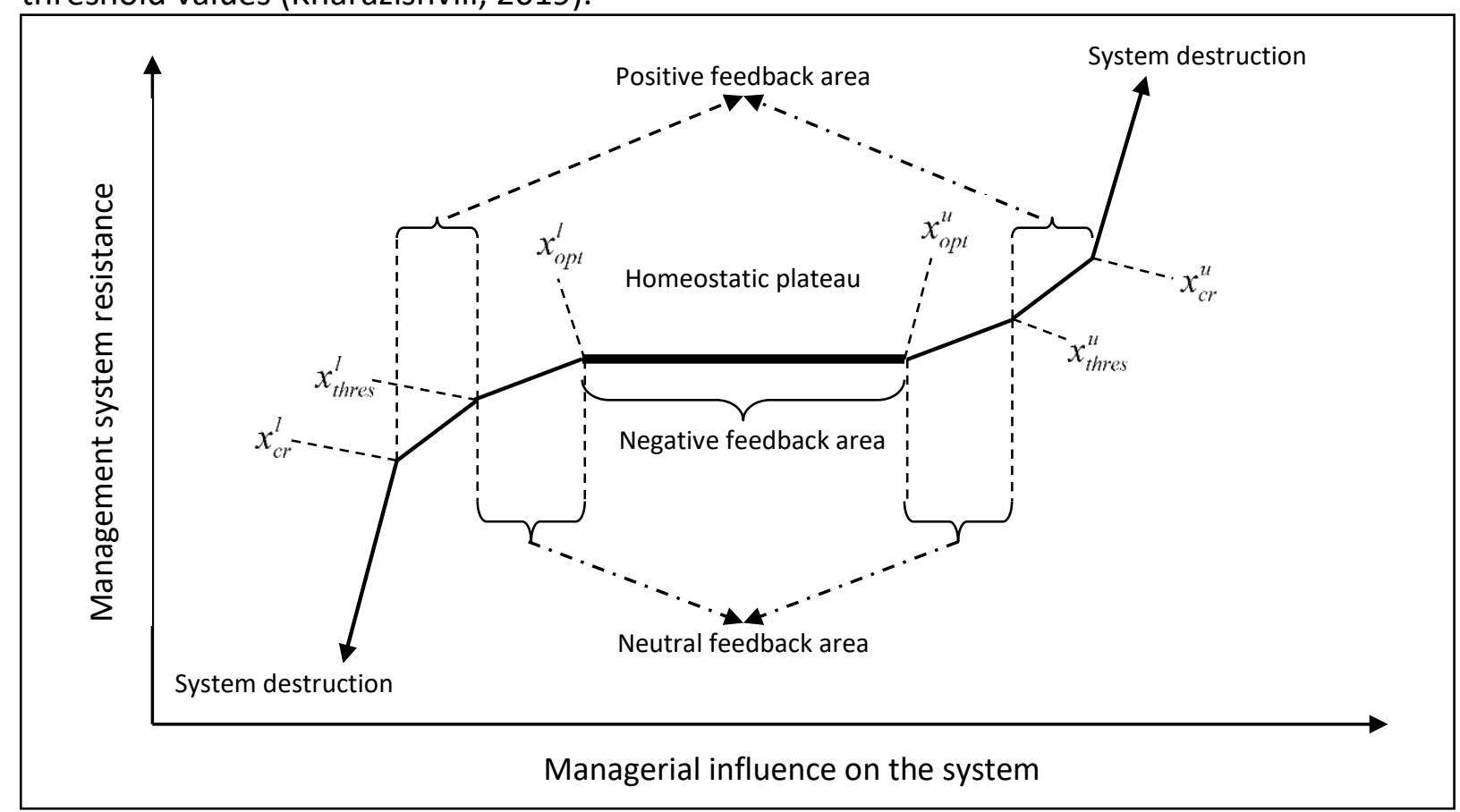

Figure 1. 'Homeostatic plateau' of the dynamic system Source: own research.

On each side of the homeostatic plateau there are areas with neutral and positive feedback, staying in which is dangerous or threatens the existence of the system in general. In this sense, monitoring of the standard of living in general, as well as according to individual components and indicators gains crucial importance for establishing the real state in comparison with the thresholds, for identifying the threats and justifying the strategic guidelines for medium and long-term development scenarios. 


\section{Comparative analysis of the living standards in Ukraine, Georgia, and Poland}

Using these methods of measuring threshold values, we calculate the vector of the threshold values of the suggested indicators and the valuation coefficients taking into account the experience of the economically developed countries. The advantage is given to the methods of functional dependencies, macroeconomic models, and stochastic process Table 1.

Table 1. Vector of threshold values of the indicators of standard of living

\begin{tabular}{lccccc}
\hline \multicolumn{1}{c}{ Indicators } & $\begin{array}{c}\text { Lower } \\
\text { threshold }\end{array}$ & $\begin{array}{c}\text { Lower } \\
\text { opt. }\end{array}$ & $\begin{array}{c}\text { Upper } \\
\text { opt. }\end{array}$ & $\begin{array}{c}\text { Upper } \\
\text { threshold }\end{array}$ & $\begin{array}{c}\text { Norm. } \\
\text { Coefficient }\end{array}$ \\
\hline - labour use level; & 0.8 & 0.9 & 0.98 & 1.0 & 1.0 \\
\hline - compensation of employees in output; & 0.2 & 0.26 & 0.32 & 0.382 & 0.382 \\
\hline $\begin{array}{l}\text { - GDP created by shadow employment and } \\
\text { wages; }\end{array}$ & 15.0 & 8.0 & 5.0 & 3.0 & 50.0 \\
\hline - shadow employment to total employment; & 20.0 & 15.0 & 10.0 & 7.0 & 37.0 \\
\hline - expenditure on education to output, \%; & 2.5 & 2.8 & 3.9 & 6.0 & 6.0 \\
\hline - healthcare expenditure to output, \%; & 4.0 & 4.9 & 6.3 & 7.4 & 7.4 \\
\hline - the ratio of average wages to a living wage; & 3.0 & 4.0 & 6.0 & 7.0 & 8.5 \\
\hline - wage share in the structure of income, \%; & 40.0 & 50.0 & 60.0 & 70.0 & 70.0 \\
\hline - pension expenditure to output, \%; & 5.0 & 8.0 & 10.0 & 11.0 & 11.0 \\
\hline - pension fund deficit to output, \%. & 1.5 & 1.0 & 0.5 & 0.25 & 4.3 \\
\hline Integral threshold values & 0.54289 & 0.68602 & 0.83742 & 0.94755 & \\
\hline
\end{tabular}

Source: own research.

Fig. 2 reflects the dynamics of the determined indicators of the standard of living for Ukraine, Georgia and Poland for 2000-2017 compared with the corresponding threshold values.

This comparison makes it possible to identify the status of individual indicators that threaten the safety of the standard of living and determine the required regulatory actions. We also would like to emphasize that it is essential to periodically revise thresholds that vary over time depending on the development level of countries.

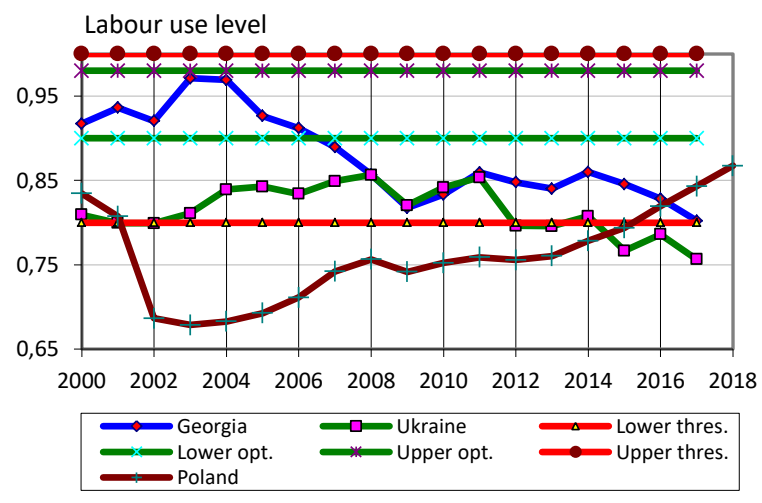

$a$

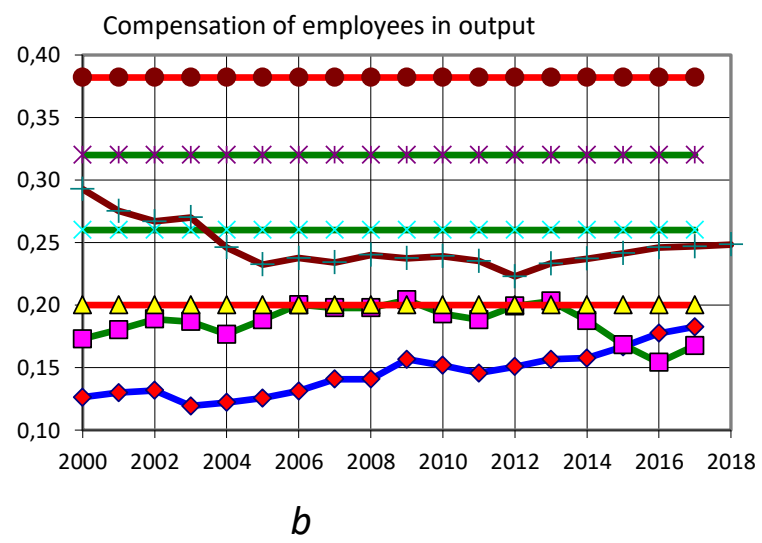

$b$

Figure 2a. Dynamics of the indicators of the standard of living in Ukraine, Georgia, and Poland (part 1)

Source: own research. 
Shadow compensation of employees, \%

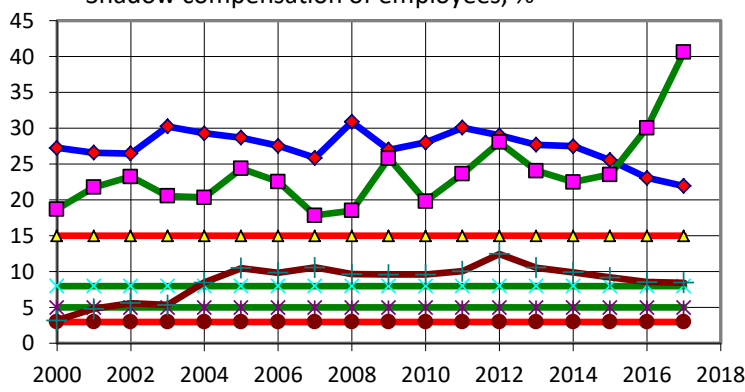

C

Expenditure on education,\%

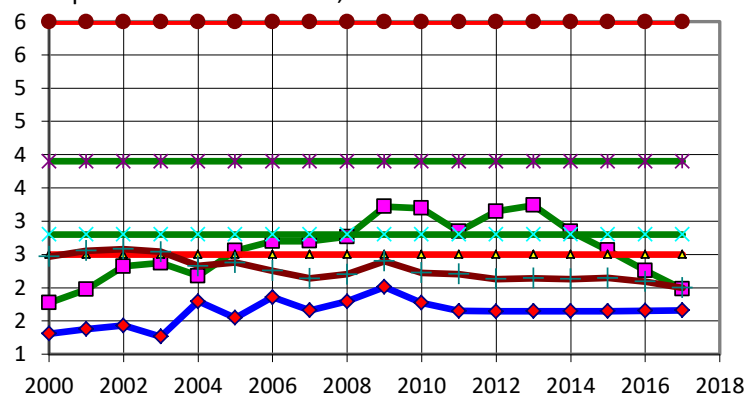

$e$

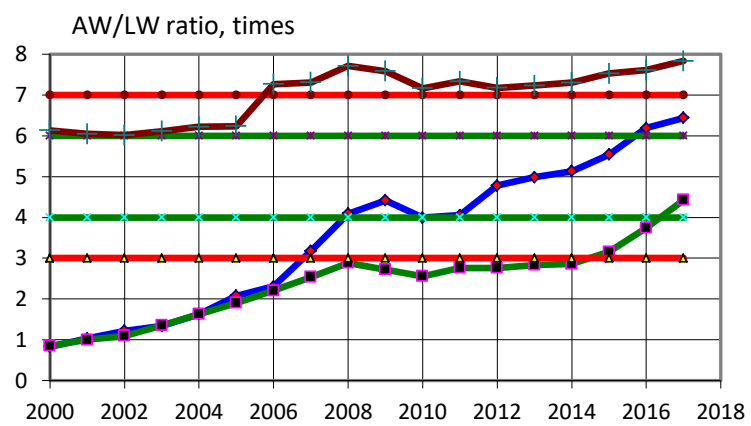

$g$

Pension expenditure, \%

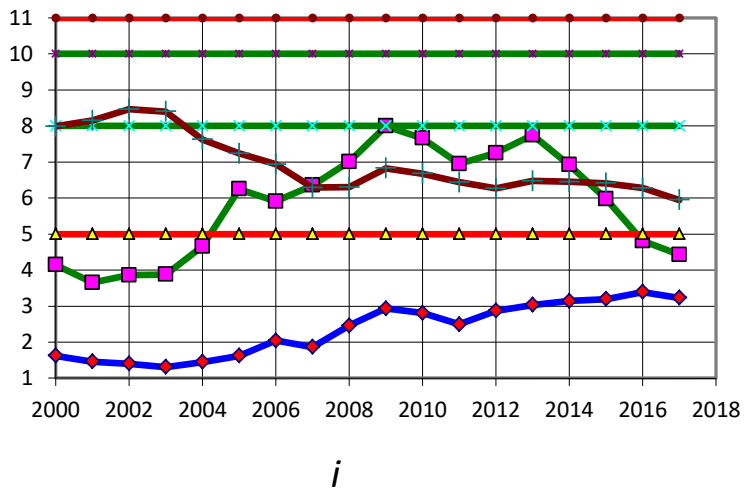

Shadow employment, \%

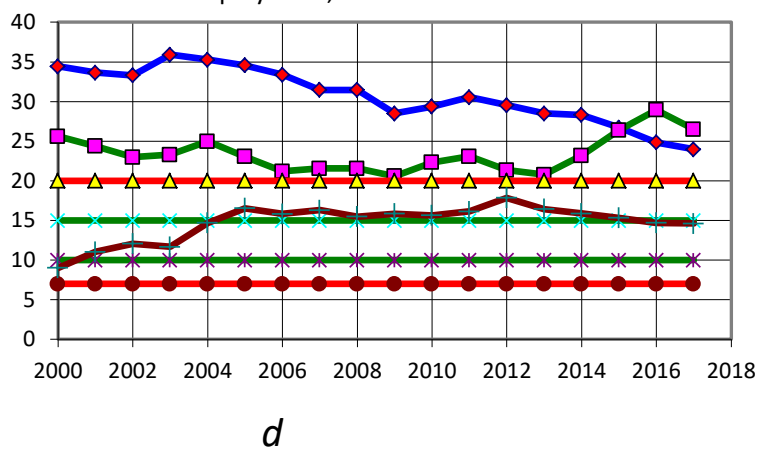

Health expenditure, \%

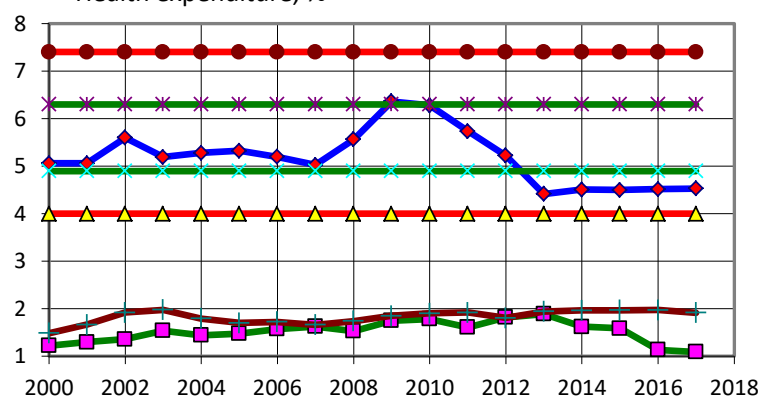

$f$

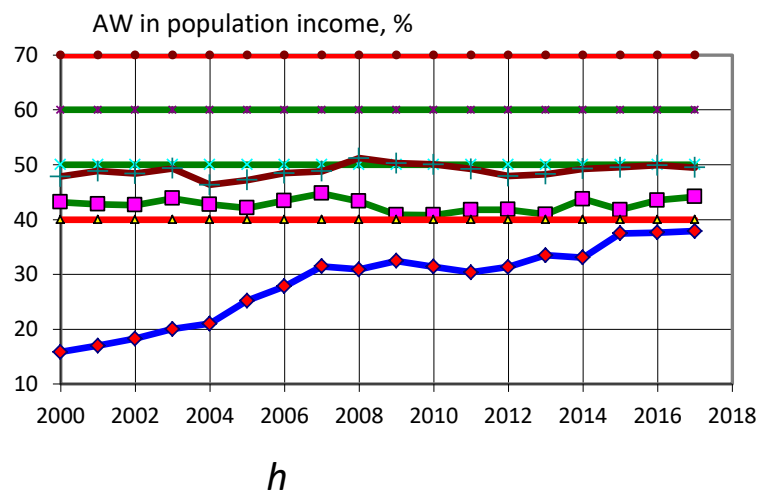

PF deficit, \%

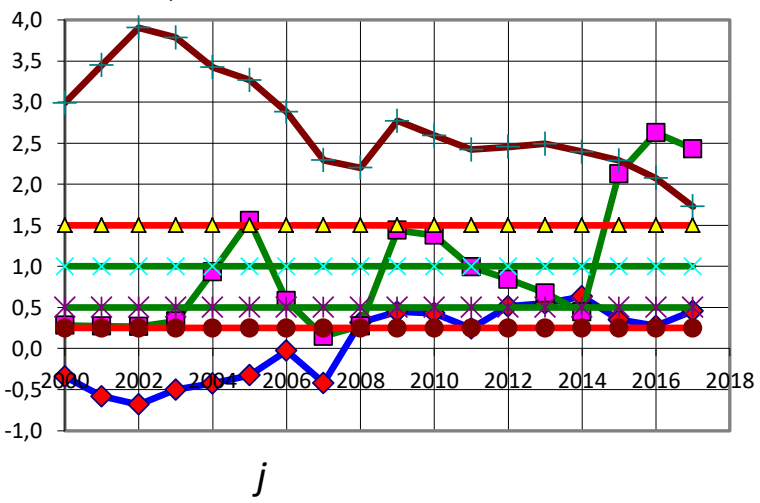

Figure 2b. Dynamics of the indicators of the standard of living in Ukraine, Georgia, and Poland (part 2)

Source: own research. 
Georgia has always surpassed Ukraine by the level of labour use and even had the best performance in 2000-2006 with a gradual decrease to the lower threshold. In Ukraine since 2012, this figure has fallen below the lower threshold and is particularly strong after 2014, reflecting a real threat. In case of Poland, in 2000-2015 this indicator was below the lower threshold, and since 2016 Poland has been outpacing both Ukraine and Georgia, possibly due to migration processes.

Ukraine has outstripped Georgia by the wage and salary share in the output which determines the average nominal wage and the level of shadow economy, till 2015, but then the situation has changed, and both countries are currently in the critical area below the lower threshold. In a radical departure from them, Poland is approaching the lower optimal value among EU countries. By the end of 2017, the overall level of shadow economy was as follows: in Ukraine $-47.4 \%$; in Georgia - 32.9\%; in Poland - 27.1\%.

After the employers paid shadow wages the indicator changed, particularly: in Ukraine it was $33.0 \%$; in Georgia - 24.5\%; in Poland - 23.8\%. Despite the anti-corruption reforms in Georgia held in 2004-2013, shadow wages and shadow employment have still been substantial, even larger than in Ukraine until 2015, and then the situation has changed. Both countries are in the critical area - below the lower threshold - according to this indicator. Unlike Poland, where shadow employment and shadow wages are constantly on the verge of the optimal range of economically developed EU member states.

According to the model estimates in 2017, the level of official GDP created by the shadow wages (taking into account the consumption multiplier) is $21.9 \%$ in Georgia, $37.8 \%$ in Ukraine, $8.5 \%$ in Poland, and shadow employment is $23.9 \%, 26.5 \%$ and $14.6 \%$ respectively.

Georgia has always been in the critical area - below the lower threshold - by the expenditure on education which indicates a very insufficient financing of education in the country. Poland demonstrates the same trend; however the level is slightly better. Ukraine has got considerably better indicators in terms of the indicator: in 2006-2014, the country was in the optimal zone which corresponds to the level of the economically developed countries of the world, and only in the last two years (2016-2017) it had negative dynamics and appeared to be in the critical area.

The situation with the health expenditure is quite the opposite: Georgia has undoubtedly the best indicators. It has been in the optimal area in 2000-2014, but the situation has somewhat deteriorated in recent years. Ukraine and Poland have had a low level of health spending throughout the analysed period: it was constantly in the critical area at the level of underdeveloped African countries which is an important cause of population decline and emigration.

Taking into account the ratio of average wages to a living wage, Poland is way over the top the indicator is 8 times higher than the standards, Georgia has already reached the EU standards by 2008 ( 4 times higher) and has continued the indicator increase up to 6.5 times in 
2017. On the contrary, by the end of 2015, Ukraine has come closer to the lower threshold of the EU countries and only in 2017 reached the value of 4.4 times. However, both in Georgia and in Ukraine, wages / salaries and living wage have significantly lowered in terms of output, unlike Poland, where the share of wages in output is approaching the lower optimal value of the developed EU member states.

The share of wages in the income of the population of Poland is at the level of lower optimal value; in Ukraine it is roughly constant: it is closer to the lower threshold, indicating both low absolute compensation of employees and high shadow employment. In Georgia, this indicator is in the critical area - below the lower threshold, but with a positive dynamics of approaching the lower threshold, indicating a gradual increase in wages and a reduction of shadow employment.

In Poland, the pension expenditure to output has a negative dynamics: from the lower optimal to the average value between the lower optimal and lower threshold. In Ukraine, this indicator in certain years (2008-2013) was almost in the optimal area, and starting in 2014, there is a clear negative dynamics, moreover the indicator has fallen below the lower threshold. Until 2008 , the pension expenditure to output in Georgia has been too low that indicates substantial reserves of its increase, if the country targets economically developed countries. The replacement rate by the end of 2017 is a conspicuous fact of low retirement expenditures, namely: in Ukraine -0.28; in Georgia - 0.2; in Poland - 0.5, considering the ILO requirements of not less than 0.4 .

If until 2014 the PF deficit in Ukraine was within acceptable limits, in the last 3 years it has reached critical values due to the low revenues of the PF due to low wages, decline in production and labour migration. In Poland, the level of PF deficit has a tendency to decrease and in the last 16 years it has declined more than twice: from 4.0 to $1.72 \%$ in 2017 . The relatively high level of PF deficit is due to higher pensions and, consequently, high replacement rates.

Georgia does not have a pension fund, and pensions are paid from the state budget. Before 2008 , there was an additional $20 \%$ social tax, but according to the changes that came into force on 1 January 2008 regarding abolishing social tax, Georgia increased the personal income tax rate from $12 \%$ to $25 \%$. Therefore, for proper comparison with Ukraine and Poland, we have modelled the virtual pension fund of Georgia, where the social tax (which does not exist in Georgia since 2008) was defined as follows:

$$
S S C=\frac{20}{20+12} \cdot 25=0.625 \cdot 25=15.625 \%
$$

while the revenues and expenditures of the virtual pension fund were calculated according [eq. (13)]. As a result of calculations, the deficit of the virtual PF of Georgia can still be increased (to the level of economically developed countries). 
Each indicator in a particular period may increase or decrease, so it is not enough to analyse individual indices or development indicators. This does not give a complete picture of the standard of living in general. For an unambiguous measuring of the living standard of the population, we will analytically determine the integral index which will ensure the methodological unity of all indicators.

Simultaneous valuation of the indicators and their threshold values with a single normalisation coefficient allows us to compare the dynamics of the integral index with integral threshold values on one scale, that is, to identify the state of living standards of the population of Georgia, Ukraine, and Poland Fig. 3.

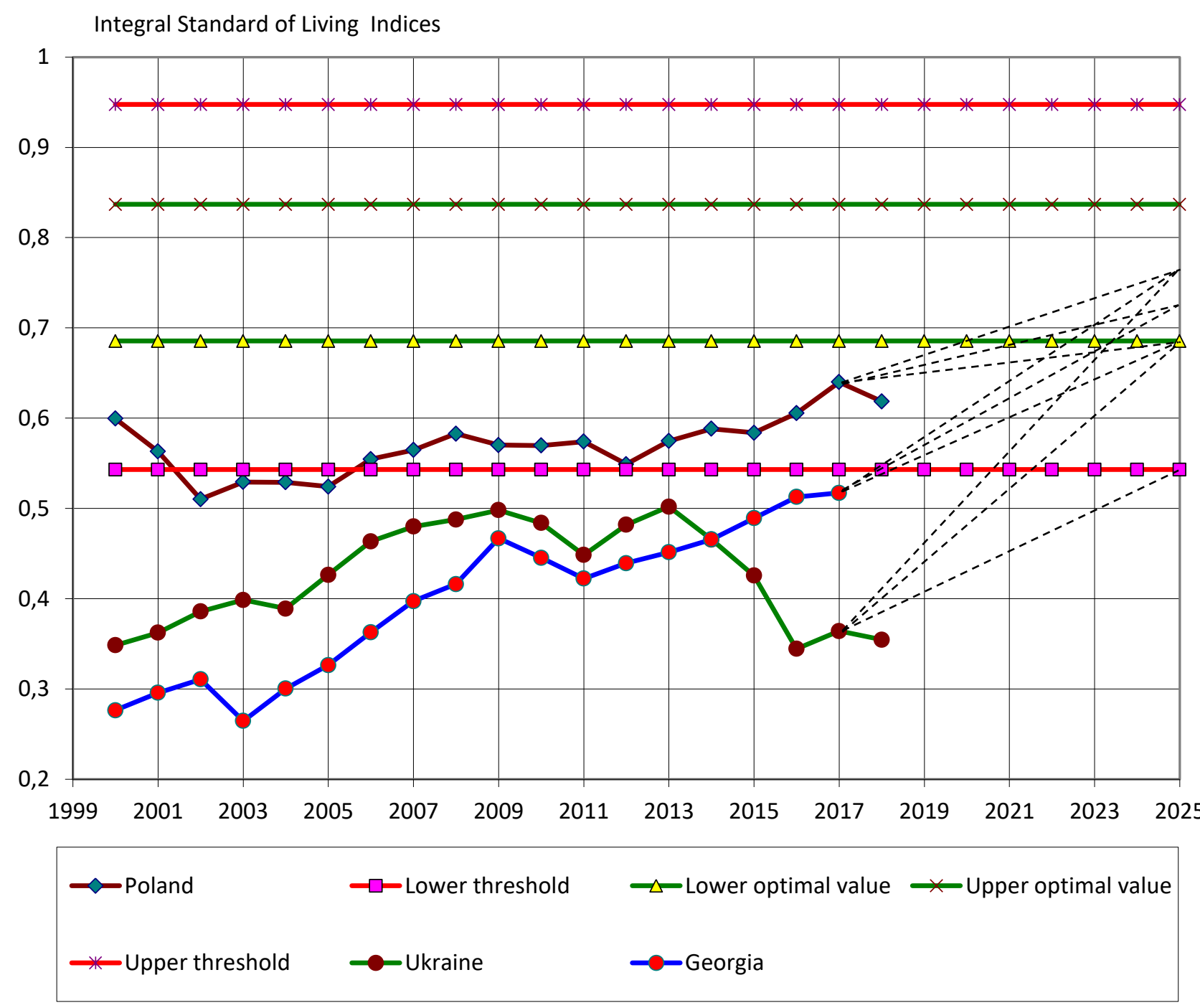

Figure 3. Dynamics of the standard of living in Georgia, Ukraine, and Poland (dotted lines reflect strategic development scenarios)

Source: own research. 
As the calculations reveal, the standard of living in Poland is the best since 2000 and since 2006 it has crossed the lower threshold and is gradually approaching the lower optimal value of economically developed EU member states. Out of the ten indicators of living standards in Poland, only two are below the lower threshold and require immediate attention: these are expenditure on education and health expenditure.

Until 2014 Georgia had the worst indicators of living standards, but since 2014 it has been ahead of Ukraine with a constant positive trend and almost approaching the lower threshold. It is notable that the analysed period can be clearly divided into two stages: 1) 2003-2009 with the development angle of about $34^{\circ}$ and 2) 2011-2017 with the development angle of about $14^{\circ}$, which is almost 2.5 times slower. This can be explained by the effectiveness of the liberal reforms in the social and economic spheres in the first period, as a result of which the Georgian economy has experienced a rapid rise, reflected in international indices, reports and ratings, as well as in the dynamics of the standard of living and our calculations confirm it.

Out of ten indicators of the standard of living in Georgia, six are below the lower threshold, thus, they are alarming and need attention: compensation of employees in output; official GDP created by the shadow wages; shadow employment to total employment; expenditure on education to output; wage share in the structure of income of the population, pension expenditure to output.

Until 2014, Ukraine has been second by the level of living standard, however afterwards there was a rapid fall, which continues to this moment. Unfortunately, unlike Georgia and Poland, the standard of living in Ukraine since 2000 has never risen above the lower threshold, indicating a systemic crisis in the social sphere. This situation is due to the critical level of the overwhelming majority of key indicators. Out of ten indicators, nine are in the critical area (below the lower threshold), one - the ratio of average wages to a living wage - in the optimal area.

Thus, the main threats to a decent standard of living in Ukraine are reflected in the indicators: labour use level, compensation of employees in output, official GDP created by shadow economy; shadow employment to total employment; expenditure on education to output; health expenditure to output; PF deficit to output. The most critical ones include the following: compensation of employees in output (indicates very low nominal wages), shadow wages (shows a high share of 'envelope' wages), health expenditure (reveals catastrophically low funding for healthcare).

Thus, the indicators of the standard of living in Ukraine (all but one) do not correspond (even in relative terms) to European standards in the first place; furthermore, they have had virtually no positive dynamics for a long time. Therefore, it is not surprising that in such conditions more and more active, motivated, highly skilled citizens have lost hope for the improvement and choose to emigrate from Ukraine to other countries. 
If this trend remains unchanged, it will lead to a sharp decline in working-age population, and, accordingly, to relevant drastic decline in social contributions, increase in the Pension Fund deficit, further decline in the standard of living and a complete loss of the economic growth potential of Ukraine.

\subsection{Scientific substantiation of the strategic targets for the standard of living}

The main objective of social policy, as well as its components, is the achievement of sustainable development. Strategic vision of sustainable development, first of all, involves defining at what distance from the desired level development are the current indicators of the standard of living. Namely, it is desirable to determine the starting point for each component of the standard of living, and then - to justify strategic benchmarks for achieving the desired level of indicators. The average value between the lower and upper optimal values - a homeostatic plateau (Kharazishvili, 2019) - within which there is a negative feedback and the best conditions for the system, is the criterion for achieving sustainable development.

Hence, let's define development scenarios Fig. 3:

For Georgia:

realistic (inertial) assumptions - reaching the lower optimal value; optimistic assumptions - reaching 0.5 of the average optimal value; sustainable development assumptions - reaching the average optimal value.

For Ukraine:

realistic (inertial) assumptions - reaching the lower threshold value;

optimistic assumptions - reaching the lower optimal value;

sustainable development assumptions - reaching the average optimal value.

For Poland:

realistic (inertial) assumptions - reaching the lower optimal value;

optimistic assumptions - reaching 0.5 of the average optimal value;

sustainable development assumptions - reaching the average optimal value.

The rationale for strategic guidelines implies solving the issue of sequential decomposition of integral indices, i.e., synthesising the necessary values of the components and their indicators for finding the integral index in the specified limits by solving the inverse problem. Solving this issue for each component of the standard of living, when known (or given) its desired value, allows determining the required values of the components and their indicators that meet the defined objectives for each year Tables 2-4, throughout the forecast period, while taking into account the sensitivity of components or indicators, weight coefficients and adaptive regulation methods of the control theory (Kharazishvili, 2019). 
Table 2. Strategic values of the indicators of standard of living in Georgia for 2025 according to sustainable development scenarios

\begin{tabular}{lccc}
\hline \multicolumn{1}{c}{ Indicator } & $\begin{array}{c}\text { Realistic } \\
\text { Scenario }\end{array}$ & $\begin{array}{c}\text { Optimistic } \\
\text { Scenario }\end{array}$ & $\begin{array}{c}\text { Sustainable } \\
\text { Development }\end{array}$ \\
\hline 1. Labour use level & 0.88893 & 0.9172 & 0.94 \\
\hline 2. Compensation of employees in output & 0.2381 & 0.2547 & 0.29 \\
\hline 3. Official GDP share created by shadow wages, \% & 15.83 & 13.95 & 6.5 \\
\hline 4. Shadow employment, \% & 17.1 & 15.16 & 12.5 \\
\hline 5. Expenditure on education, \% & 2.55 & 2.75 & 3.35 \\
\hline 6. Healthcare expenditure, \% & 5.21 & 5.42 & 5.6 \\
\hline 7. Ratio of average wages to a living wage, \% & 7.02 & 7.21 & 5.0 \\
\hline 8. Wage share in the structure of income, \% & 47.1 & 49.9 & 55 \\
\hline 9. Pension expenditure in output, \% & 4.92 & 5.39 & 9.0 \\
\hline 10. PF deficit (-)/ surplus (+) in output, \% & -1.73 & -2.09 & -4.33 \\
\hline
\end{tabular}

Source: own research.

Using the appropriate equations for calculating the indicators of each component of the standard of living and the normalisation equations in the reverse order, one can obtain strategic benchmarks for key macro-indicators.

Table 3. Strategic values of the indicators of standard of living in Ukraine for 2025 according to sustainable development scenarios

\begin{tabular}{lccc}
\hline \multicolumn{1}{c}{ Indicator } & $\begin{array}{c}\text { Realistic } \\
\text { Scenario }\end{array}$ & $\begin{array}{c}\text { Optimistic } \\
\text { Scenario }\end{array}$ & $\begin{array}{c}\text { Sustainable } \\
\text { Development }\end{array}$ \\
\hline 1. Labour use level & 0.8176 & 0.88884 & 0.94 \\
\hline 2. Compensation of employees in output & 0.2163 & 0.2693 & 0.29 \\
\hline 3. Official GDP share created by shadow wages, \% & 29.02 & 19.42 & 6.5 \\
\hline 4. Shadow employment, \% & 20.57 & 13.94 & 12.5 \\
\hline 5. Expenditure on education, \% & 2.73 & 3.78 & 3.35 \\
\hline 6. Healthcare expenditure, \% & 2.97 & 4.60 & 5.6 \\
\hline 7. Ratio of average wages to a living wage, \% & 5.59 & 6.28 & 5 \\
\hline 8. Wage share in the structure of income, \% & 42.25 & 48.06 & 55 \\
\hline 9. Pension expenditure in output, \% & 5.53 & 6.83 & 9.0 \\
\hline 10. PF deficit (-)/ surplus (+) in output, \% & -1.63 & -1.97 & -3.76 \\
\hline
\end{tabular}

Source: own research. 
Table 4. Strategic values of the indicators of standard of living in Poland for 2025 according to sustainable development scenarios

\begin{tabular}{lccc}
\hline \multicolumn{1}{c}{ Indicator } & $\begin{array}{c}\text { Realistic } \\
\text { Scenario }\end{array}$ & $\begin{array}{c}\text { Optimistic } \\
\text { Scenario }\end{array}$ & $\begin{array}{c}\text { Sustainable } \\
\text { Development }\end{array}$ \\
\hline 1. Labour use level & 0.8773 & 0.9066 & 0.94 \\
\hline 2. Compensation of employees in output & 0.2656 & 0.2814 & 0.29 \\
\hline 3. Official GDP share created by shadow wages, \% & 6.59 & 4.99 & 6.5 \\
\hline 4. Shadow employment, \% & 12.69 & 11.07 & 12.5 \\
\hline 5. Expenditure on education, \% & 2.27 & 2.49 & 3.35 \\
\hline 6. Healthcare expenditure, $\%$ & 2.32 & 2.63 & 5.6 \\
\hline 7. Ratio of average wages to a living wage, \% & 8.1 & 8.33 & 5.0 \\
\hline 8. Wage share in the structure of income, \% & 52.47 & 55.0 & 55.0 \\
\hline 9. Pension expenditure in output, $\%$ & 6.29 & 6.58 & 9.0 \\
\hline 10. PF deficit (-)/ surplus (+) in output, $\%$ & -1.05 & -1.21 & -2.56 \\
\hline
\end{tabular}

Source: own research.

These macro-indicators, along with the strategic values of the indicators, are the ultimate goal of regulation required in order to achieve the anticipated standard of living for the population of Georgia, Ukraine, and Poland Tables 5-7.

Table 5. Change the most important macro-level indicators in Georgia for 2025 according to sustainable development scenarios

\begin{tabular}{lccc}
\hline \multicolumn{1}{c}{ Indicator } & $\begin{array}{c}\text { Realistic } \\
\text { Scenario }\end{array}$ & $\begin{array}{c}\text { Optimistic } \\
\text { Scenario }\end{array}$ & $\begin{array}{c}\text { Sustainable } \\
\text { Development }\end{array}$ \\
\hline Gross domestic product (nom.), billion GEL & 94.53 & 137.07 & 179.6 \\
\hline Average GDP growth rate, \% & 6.1 & 11.2 & 15.0 \\
\hline Optimal demand for labour, million people & 1.867 & 1.926 & 1.974 \\
\hline Nominal wage, GEL/ month & $2,414.8$ & $3,631.7$ & $5,286.5$ \\
\hline Shadow wage, GEL/ month & $2,569.6$ & $3,704.6$ & $2,742.4$ \\
\hline Shadow employment, million people & 0.1881 & 0.1667 & 0.1375 \\
\hline Official GDP share created by shadow wages, \% & 15.83 & 13.95 & 6.5 \\
\hline Expenditure on education, billion GEL & 3.67 & 5.77 & 9.95 \\
\hline Health expenditure, billion GEL & 8.14 & 12.29 & 16.62 \\
\hline Living wage, GEL/ month & 343.8 & 503.7 & 1057.3 \\
\hline Minimum wage, GEL/ month & $1,207.4$ & $1,815.9$ & $2,643.2$ \\
\hline Pension expenditure, billion GEL & 7.69 & 12.23 & 23.7 \\
\hline Average monthly pension, GEL & 660.4 & $1,050.8$ & $2,040.3$ \\
\hline Replacement rate & 0.2735 & 0.2893 & 0.3859 \\
\hline Deficit (-)/ surplus (+), \% of output & -1.732 & -2.092 & -4.327 \\
\hline Source: own research
\end{tabular}


Table 6. Change of the most important macro-level indicators in Ukraine for 2025 according to sustainable development scenarios

\begin{tabular}{|c|c|c|c|}
\hline Indicator & $\begin{array}{l}\text { Realistic } \\
\text { Scenario } \\
\end{array}$ & $\begin{array}{c}\text { Optimistic } \\
\text { Scenario }\end{array}$ & $\begin{array}{c}\text { Sustainable } \\
\text { Development }\end{array}$ \\
\hline Gross domestic product (nom.), billion UAH & $6,081.4$ & $11,554.3$ & $22,702.0$ \\
\hline Average GDP growth rate, $\%$ & -3.5 & 4.5 & 14.3 \\
\hline Optimal demand for labour, million people & 16.35 & 17.77 & 18.8 \\
\hline Nominal wage, $U A H /$ month & $16,123.0$ & $35,093.0$ & $70,179.0$ \\
\hline Shadow wage, $U A H /$ month & $16,942.8$ & $31,790.5$ & $20,853.0$ \\
\hline Shadow employment, million people & 3.364 & 2.279 & 2.044 \\
\hline Official GDP share created by shadow wages, \% & 29.0 & 19.42 & 6.5 \\
\hline Expenditure on education, billion $U A H$ & 316.1 & 831.6 & $1,448.6$ \\
\hline Health expenditure, billion $U A H$ & 344.3 & $1,012.6$ & $2,421.6$ \\
\hline Living wage, $U A H /$ month & $2,884.6$ & $5,585.3$ & $14,035.8$ \\
\hline Minimum wage, $U A H /$ month & $8,061.5$ & $17,546,6$ & $35,089.5$ \\
\hline Pension expenditure, billion UAH & 640.9 & $1,504.3$ & $3,891.9$ \\
\hline Average monthly pension, $U A H$ & $4,450.5$ & $10,446.7$ & $27,027.3$ \\
\hline Replacement rate & 0.276 & 0.2977 & 0.3881 \\
\hline Deficit (-)/ surplus (+), \% of output & -1.627 & -1.974 & -3.764 \\
\hline
\end{tabular}

Source: own research.

Table 7. Change of the most important macro-level indicators in Poland for 2025 according to sustainable development scenarios

\begin{tabular}{lccc}
\hline \multicolumn{1}{c}{ Indicator } & $\begin{array}{c}\text { Realistic } \\
\text { Scenario }\end{array}$ & $\begin{array}{c}\text { Optimistic } \\
\text { Scenario }\end{array}$ & $\begin{array}{c}\text { Sustainable } \\
\text { Development }\end{array}$ \\
\hline Gross domestic product (nom.), billion PLN & $2,902.6$ & $3,631.3$ & $5,083.2$ \\
\hline Average GDP growth rate, $\%$ & 3.8 & 6.7 & 11.5 \\
\hline Optimal demand for labour, million people & 16.36 & 16.91 & 17.53 \\
\hline Nominal wage, $P L N /$ month & $7,234.0$ & $9,278.0$ & $15,573.6$ \\
\hline Shadow wage, $P L N /$ month & $2,864.3$ & $3,109.4$ & $5,022.8$ \\
\hline Shadow employment, million people & 2.157 & 1.883 & 2.125 \\
\hline Official GDP share created by shadow wages, \% & 6.59 & 4.99 & 6.5 \\
\hline Expenditure on education, billion $P L N$ & 131.7 & 180.7 & 340.6 \\
\hline Health expenditure, billion $P L N$ & 134.5 & 191.3 & 569.4 \\
\hline Living wage, $P L N /$ month & 892.8 & $1,113.4$ & $3,114.7$ \\
\hline Minimum wage, $P L N /$ month & $3,617.0$ & $4,639.0$ & $7,786.8$ \\
\hline Pension expenditure, billion $P L N$ & 365.2 & 478.1 & 915.1 \\
\hline Average monthly pension, $P L N$ & $3,307.6$ & $4,330.6$ & $8,288.8$ \\
\hline Replacement rate & 0.4572 & 0.4667 & 0.5322 \\
\hline Deficit (-)/ surplus (+), \% of output & -1.05 & -1.212 & -2.56 \\
\hline
\end{tabular}

Source: own research. 
Strategic benchmarks for the standard of living defined for each year basing on the sensitivity of the impact of each individual indicator on the integral index, are, in essence, strategic plans for the medium to long-term perspective. The identified strategic benchmarks of the standard of living at the level of indicators and macro-indicators are necessary for comparing with the actual values during monitoring, for determining the proximity to the preferred sustainable development indicators and the effectiveness of macroeconomic policy activities.

\section{Conclusions}

1. We define the standard of living as a complex socio-economic category that reflects the level of development of the physical, spiritual and social needs of the population, the degree of their satisfaction available to a person, and conditions for the development and satisfaction of these needs existing in a society. A high standard of living is the objective and criterion of the effectiveness of socio-economic policy, a prerequisite for human development, an element of social security. The article suggests a list of the indicators of the standard of, taking into account shadow employment and shadow wages, without which the assessment of standard of living is inadequate.

2. Without knowing the boundaries of safe conditions for the economic system functioning, it is impossible to protect its vital interests. Therefore, we substantiated the vectors of the threshold values for each indicator (lower threshold, lower optimal value, upper optimal value, and upper threshold), taking into account the experience of economically developed EU countries, which, in fact, gives an opportunity to identify the standard of living of Georgia, Ukraine and Poland.

3. The research assessed and identified the standard of living of the population of Georgia, Ukraine and Poland according to the author's modern methodology of integral assessment, which also revealed the main threats. This allows us to determine how far the components of the standards of living in Georgia, Ukraine, and Poland are from the sustainable development indicators:

- the integral index of the standard of living in Georgia has positive dynamics and approaches the lower optimal value of the EU member states. However, out of ten indicators of the standard of living in Georgia, six are below the lower threshold, thus, they pose a threat to a decent standard of living;

- for the last 17 years the integral index of the standard of living in Ukraine has been below the critical value (lower threshold). This demonstrates a consistently low level of living, which got even worse over the last three years. This poses a threat to national security from the side of society. The given situation is due to the unsatisfactory level of the vast majority of the indicators of standard of living. Out of ten indicators, nine pose a threat to a decent standard of living;

- the integral index of the standard of living in Poland is the best among the three countries, since 2006 it has crossed the lower threshold and is gradually approaching the lower optimal value of economically developed EU member states. Out of the ten indicators of living 
standards in Poland, only two are below the lower threshold and require immediate attention: these are expenditure on education and health expenditure.

4. The article advocates three strategic development scenarios aiming to raise the standard of living of the population of Georgia, Ukraine and Poland by 2025: realistic, optimistic and sustainable development scenarios. They scientifically substantiate strategic benchmarks with the use of adaptive regulation methods of the control theory through the definition of target benchmarks and decomposition of integral indexes. The values of the standard of living indicators and relevant macro-indicators that provide the desired development are the ultimate result of strategic planning.

5. The identified strategic benchmarks for sustainable development at the level of indicators are, in their essence, a strategy for raising the standard of living of the population of Georgia, Ukraine and Poland. They are necessary for comparing with the actual values during monitoring, for determining the proximity to the preferred sustainable development indicators and the effectiveness of macroeconomic policy activities. It is evidenced that the use of realistic and optimistic strategic development scenarios preserves the disproportionality to varying degrees, and only full implementation of the agenda for sustainable development eliminates this disproportionality. The sustainable development scenario foresees reaching the average optimal values of the indicators (sustainable development criteria): an increase in the share of wages in output and, consequently, a significant increase in wages and a decrease in the shadow economy that solves the problem of the standard of living and the budget deficit of Georgia, Ukraine and Poland.

6. Practical implementation of the noted scenarios of the standard of living in Ukraine is impossible without a significant reduction of corruption and shadow economy. Effective system reforms, including the transfer of executive power to artificial intelligence (smart robots), are still an absolute must; they are required to overcome corruption at all levels of power and change the negative trends in socio-economic policies. This is the only way how we can stop the destruction of the middle class, total emigration, and depopulation, restore faith and confidence in state power, assure economic growth and increase the standard of living.

\section{References}

Amosha, O., \& Novikova, O. (2011). Sotsialna vidpovidalnist v konteksti rozvytku liudskoho potentsialu [Social Responsibility in the Context of Human Potential Development]. Derzhava i suspilstvo [State and Society], 2, 122-127 [in Ukrainian].

Amosha, O., Kharazishvili, Y., Liashenko, V., \& Kvilinskyi, O. (2016). Economic security of sustainable development of the regions (based on the example of the Donetsk region). In K. Pająk (Ed.), Gospodarka niskoemisyjna i jej wpływa na rozwój województwa wielkopolskiego [Low-carbon economy and its impact on the development of the Wielkopolska voivodship] (pp. 19-34). Warsaw, Poland: Wydawnictwo Naukowe PWN.

Antoniuk, V., Hrinevska, S., \& Prohnimak, O. (2012). Hidnyi riven ta yakist zhyttia naselennia $v$ konteksti formuvannia sotsialnoho potentsialu staloho rozvytku: nauk. dopovid [Decent Level and Quality of 
Life of the Population in the Context of Forming the Social Potential of Sustainable Development: Scientific Report]. Donetsk, Ukraine: Institute of Industrial Economics, National Academy of Sciences of Ukraine [in Ukrainian].

Arts, K. (2017). Inclusive sustainable development: a human rights perspective. Current Opinion in Environmental Sustainability, 24, 58-62. https://doi.org/10.1016/j.cosust.2017.02.001

Bilan, Y., Vasylieva, T., Lyulyov, O., \& Pimonenko T. (2019). EU vector of Ukraine development: linking between macroeconomic stability and social progress. International journal of business and society, 20(2), 433-450.

Biermann, F., Kanie, N., \& Kim R.E. (2017). Global governance by goal-setting: the novel approach of the UN Sustainable Development Goals. Current Opinion in Environmental Sustainability, 26-27, 26-31. https://doi.org/10.1016/j.cosust.2017.01.010

Cherenko, L. (Ed.). (2006). Riven zhyttia naselennia Ukrainy [The Standard of Living of the Population of Ukraine]. Kyiv, Ukraine: Publishing House "Konsultant" [in Ukrainian].

Dźwigoł, H., \& Dźwigoł-Barosz, M. (2018). Scientific research methodology in management sciences. Financial and Credit Activity: Problems of Theory and Practice, 2(25), 424-437. https://doi.org/10.18371/fcaptp.v2i25.136508

Głowski, P., \& Kvilinskyi, O. (Eds.). (2017). Economic transformation in Ukraine: comparative analysis and European experience. Warsaw: Consilium Sp. z o.o.

Grishnova, O., Kharazishvili, Y. (2018). Improving the Standard of Living as a Strategic Priority of Ukraine and Georgia. In D. Lukianenko and T. Beridze (Eds.), Strategic Priorities for Developing Ukraine and Georgia: Innovation and Partnership (pp. 245-277). Batumi, Georgia: Batumi Navigation Teaching University.

Ivanov, S., Liashenko, V., Kamińska, B., \& Kvilinskyi, O. (2017). Koncepcja oceny modernizacji [A concept of modernization evaluation]. Współpraca Europejska-[European Cooperation], 12(19), 86-101 [in Polish].

Kaźmierczyk, J., \& Akulich, M. (2018a). The socio-economic approach to the study of main economic systems. Socialism and capitalism. Part 1. Management 22(1): 238-250. https://doi.org/10.2478 /manment- 2018-0017

Kaźmierczyk, J., \& Akulich, M. (2018b). The socio-economic approach to the study of modern economic systems. Post-capitalism. Part 2. Management 22(2), 299-310. https://doi.org/10.2478/manment2018-0038

Kharazishvili, Yu., \& Liubich, O. (2006). Systemne modeliuvannia sotsialno-ekonomichnoho rozvytku Ukrainy [System Modelling of Social and Economic Development of Ukraine]. Bankivska sprava [Banking], 2, 46-65 [in Ukrainian].

Kharazishvili, Yu. (2014). Metodolohichni pidkhody do otsinky rivnia ekonomichnoi bezpeky derzhavy [Methodological Approaches to Assessment of the Level of Economic Security of the State]. Nauka ta naukoznavstvo [Science and Science Studies], 4, 44-58 [in Ukrainian].

Kharazishvili, Y., Lyashenko, V., Zaloznova, Y., \& Kvilinskyi, O. (2016). Impact of infrastructure component on socioeconomic approach to modernization of the region. European Cooperation, 8(15), 108-119. 
Kharazishvili, Yu. (2019). Systemna bezpeka staloho rozvytku: instrumentarii otsinky, rezervy ta stratehichni stsenarii realizatsii [Systemic Safety of Sustainable Development: Assessment Tools, Reserves and Strategic Implementation Scenarios]. Kyiv, Ukraine: Institute of Industrial Economics of the National Academy of Sciences of Ukraine [in Ukrainian].

Kolot, A. (2010). Mify sotsialnoi politiki ili s chego sleduet nachinat formirovanie novoi modeli [The Myths of Social Policy or How One Should Start the Formation of a New Model]. Zerkalo nedeli [Mirror of the Week], 2(781). Retrieved from https://zn.ua/SOCIETY/mify_sotsialnoy_politiki, ili_s_chego_sleduet_nachat_formirovanie_novoy_modeli.html [in Russian].

Koval, O. (2012). Perspektyvy vprovadzhennia zahalnooboviazkovoi nakopychuvalnoi pensiinoi systemy $\checkmark$ Ukraini: vplyv na ekonomichnu bezpeku [Prospects for the Introduction of a Compulsory Accumulative Pension System in Ukraine: Impact on Economic Security]. Kyiv, Ukraine: NISS [in Ukrainian].

Koval, O. (2016). Sotsialna bezpeka: sutnist ta vymir. Naukova dopovid. [Social Security: Essence and Measurement. Scientific Report]. Kyiv, Ukraine: The National Institute for Strategic Studies [in Ukrainian].

Kvilinskyi, O., Mieshkov, A., \& Bondaryeva, I. (2017). Investigation of the social factors of development of society in the territories with transforming environment. Research Papers in Economics and Finance, 2(2), 13-19. https://doi.org/10.18559/ref.2017.2.2

Kwilinski, A. (2018). Mechanism of modernization of industrial sphere of industrial enterprise in accordance with requirements of the information economy. Marketing and Management of Innovations, 4, 116-128. http://doi.org/10.21272/mmi.2018.4-11

Libanova, E., Gladun, O., Lisohor, L. et al. (2013). Vymiriuvannia yakosti zhyttia v Ukraini: analitychna dopovid [Measuring the Quality of Life in Ukraine: Analytical Report]. Kyiv, Ukraine: Ptukha Institute for Demography and Social Studies of NAS of Ukraine, UNDP, Ministry of Economic Development and Trade of Ukraine [in Ukrainian].

Laiko, O.; \& Kwiliński, A. (2017). Tools for the Improving of Investment Climate in Territorial Communities: Challenges and Perspectives for Ukrainian Economy. Economics. Ecology. Socium, 1(1), 93-103. Retrieved from https://ees-journal.com/index.php/journal/article/view/9/3

Lakhno, V., Malyukov, V., Bochulia, T., Hipters, Z., Kwilinski, A., \& Tomashevska, O. (2018). Model of managing of the procedure of mutual financial investing in information technologies and smart city systems. International Journal of Civil Engineering and Technology, 9(8), 1802-1812. Retrieved from http://www.iaeme.com/MasterAdmin/UploadFolder/IJCIET_09_08_181/IJCIET_09_08_181.pdf

Mazurkiewicz, J., \& Lis, P. (2018). Diversification of energy poverty in Central and Eastern European countries. Virtual Economics, 1(1), 26-41. https://doi.org/10.34021/ve.2018.01.01(2)

Mishchuk, H., Samoliuk, N., Bilan, Y., \& Streimikiene, D. (2018). Income Inequality and Its Consequences within the Framework of Social Justice. Problemy Ekorozwoju [Problems of Sustainable Development], 13(2), 131-138.

Ngo, D. K. L. (2018). A theory-based living standards index for measuring poverty in developing countries. Journal of Development Economics, 130, 190-202. https://doi.org/10.1016/ j.jdeveco.2017.10.011 
Novikova, O., Sydorchuk, O., Pankova, O. et al. (2018). Stan ta perspektyvy sotsialnoi bezpeky v Ukraini: ekspertni otsinky: monohrafiia [Status and Prospects of Social Security in Ukraine: Expert Assessments. Monograph]. Kyiv, Ukraine: LRIPA NAPA [in Ukrainian].

Pająk, K., Dahlke, P., \& Kvilinskyi, O. (2016a). Determinanty rozwoju regionalnego - współczesne odniesienie [Determinants of the regional development - contemporary reference]. Roczniki Ekonomiczne Kujawsko-Pomorskiej Szkoły Wyższej w Bydgoszczy, 9, 109-122 [in Polish].

Pająk, K., Kamińska, B., \& Kvilinskyi, O. (2016b). Modern trends of financial sector development under the virtual regionalization conditions. Financial and Credit Activity: Problems of Theory and Practice, 2(21), 204-217. https://doi.org/10.18371/fcaptp.v2i21.91052

Paniotto, V., Maksymenko, V., \& Kharchenko, N. (2004). Statystychnyi analiz sotsiolohichnykh danykh [Statistical Analysis of Sociological Data]. Kyiv, Ukraine: Publishing House "KM Akademiia" [in Ukrainian].

Peker, S., Tvaronavičienè, M., \& Aktan, B. (2014). Sustainable risk management: fuzzy approach to volatility and application on FTSE 100 index. Entrepreneurship and Sustainability Issues, 2(1), 30-36. https://doi.org/10.9770/jesi.2014.2.1(4)

Raudeliūnienè, J., Tvaronavičienė, M., Dzemyda, I., \& Sepehri, M. (2014). Sustainable entrepreneurship through energy stewardship: role of values and behavioral patterns. Entrepreneurship and Sustainability Issues, 2(2), 107-117. http://dx.doi.org/10.9770/jesi.2014.2.2(6)

Shapoval, M., \& Viter, V. (2007). Bidnist - problema planetarnoho masshtabu [Poverty is a Problem of Global Scale]. Uriadovyi kurier [Governmental Courier], April 11, 6 [in Ukrainian].

Tarasevich, L., Galperin, V., Grebennikov, P., \& Leusskii, A. (1999). Makroekonomika [Macroeconomics]. St. Petersburg: Publishing House SPbGUEF [in Russian].

Trzeciakowski, R. (2018, December 4). Poland's Independence and Standard of Living in Poland. Retrieved from http://4liberty.eu/polands-independence-and-standard-of-living-in-poland/

Tkachenko, V., Kwilinski, A., Korystin, O., Svyrydiuk, N., Tkachenko, I. (2019). Assessment of information technologies influence on financial security of economy. Journal of Security and Sustainability Issues, 8(3), 375-385. http://doi.org/10.9770/jssi.2019.8.3(7)

Tvaronavičienė, M., Šimelytė, A., \& Lace, N. (2014). Sustainable development facets: exporting industrial sectors from inside. Journal of Security and Sustainability Issues, 3(4), 37-44. http://dx.doi.org/10.9770/jssi.2014.3.4(4)

Vosylius, E., Rakutis, V., \& Tvaronavičienè, M. (2013). Economic growth, sustainable development and energy security interrelation. Journal of Security and Sustainability Issues, 2(3), 5-14. http://dx.doi.org/10.9770/jssi.2013.2.3(1)

Van Gigch, J. (1981). Prikladnaia obshchaia teoriia sistem [Applied General Systems Theory]. Moscow: Mir [in Russian].

Winiarczyk-Razniak, A. \& Razniak, R. (2011). Regional differences in the standard of living in Poland (based on selected indices). Procedia Social and Behavioral Sciences, 19, 31-36. https://doi.org/10.1016/j.sbspro.2011.05.103 
Yang, P., Yao, Y. F., Mi, Z., Cao, Y. F., Liao, H., Yu, B. Y., Liangadef, Q. M., Coffmanb, D. M., \& Wei, Y. M. (2018). Social cost of carbon under shared socioeconomic pathways. Global Environmental Change 53, 225-232. https://doi.org/10.1016/j.gloenvcha.2018.10.001

Yakubovskiy, M., Liashenko, V., Kamińska, B., \& Kvilinskyi, O. (2017). Economy modernization of industrial regions (based on the example of Ukraine). In P. Głowski, \& O. Kvilinskyi (Eds.), Economic transformation in Ukraine: comparative analysis and European experience (pp. 12-29). Warsaw: Consilium Sp. z o.o.

Yevdokimov, Y., Chygryn, O., Pimonenko, T., \& Lyulyov, O. (2018). Biogas as an alternative energy resource for Ukrainian companies: EU experience. Innovative Marketing, 14(2), 7-15. doi:10.21511/im.14(2).2018.01

Zavora, T. M., \& Chepurnyi, O. V. (2013). Pidvyshchennia sotsialnykh standartiv u konteksti zabezpechennia natsionalnoi bezpeky derzhavy u sotsialnii sferi [Improving Social Standards in the Context of Ensuring National Security of the State in Social Sphere]. Retrived from http://www.rusnauka.com/30 OINXXI 2013/Economics/13 146887.doc.htm [in Ukrainian]. 